\title{
Expression of Concern: Hybrid auto-regressive neural network model for estimating global solar radiation in Bandar Abbas, Iran
}

\author{
Shahaboddin Shamshirband ${ }^{1} \cdot$ Kasra Mohammadi $^{2} \cdot$ Jamshid Piri $^{3} \cdot$ Dalibor Petkovic $^{4} \cdot$ Ahmad Karim $^{1}$
}

Published online: 1 July 2020

○) Springer-Verlag GmbH Germany, part of Springer Nature 2020

\section{Correction to: Environ Earth Sci (2016) 75:172 https://doi.org/10.1007/s12665-015-4970-x}

The Editors-in-Chief of Environmental Earth Sciences are issuing an editorial expression of concern to alert readers that this original article shows substantial indication of irregularities in authorship during the submission process. The authors suggested peer reviewers whose identity was not possible to verify. This article contains overlap with (Gani et al. 2016; Mohammadi et al. 2016; Shamshirband et al. 2015) (amongst others). Ahmad Karim has not explicitly stated whether he agrees to this editorial expression of concern. None of the other co-authors responded to correspondence about this editorial expression of concern.

The original article can be found online at https://doi.org/10.1007/ s12665-015-4970-x.

Shahaboddin Shamshirband

shamshirband@um.edu.my

Kasra Mohammadi

kmohammadi@umass.edu

1 Department of Computer System and Technology, Faculty of Computer Science and Information Technology,

University of Malaya, 50603 Kuala Lumpur, Malaysia

2

Department of Mechanical and Industrial Engineering, University of Massachusetts, Amherst, MA 01003, USA

3 Department of Water Engineering, Soil and Water College, University of Zabol, Zabol, Iran

4 Department for Mechatronics and Control, Faculty of Mechanical Engineering, University of Niš, Aleksandra Medvedeva 14, 18000 Niš, Serbia

\section{References}

Gani A, Mohammadi K, Shamshirband S et al (2016) Theor Appl Climatol 125:679. https://doi.org/10.1007/s00704-015-1533-8

Mohammadi K, Shamshirband S, Danesh AS et al (2016) Theor Appl Climatol 125:101. https://doi.org/10.1007/s00704-015-1487-x

Shamshirband S, Mohammadi K, Chen HL et al (2015) J Atmos Solar Terr Phys 134:109-117. https://doi.org/10.1016/j.jastp .2015.09.014

Publisher's Note Springer Nature remains neutral with regard to jurisdictional claims in published maps and institutional affiliations. 